\title{
Reduced Brain Natriuretic Peptide Levels in Class III Obesity: The Role of Metabolic and Cardiovascular Factors
}

\author{
Alline Beleigoli Maria Diniz Maria Nunes Marcia Barbosa Stephanie Fernandes \\ Mery Abreu Antonio Ribeiro
}

Universidade Federal de Minas Gerais, Belo Horizonte, Brazil

\section{Keywords \\ Class III obesity · Brain natriuretic peptide . \\ Metabolic syndrome $\cdot$ Heart failure}

\section{Summary}

Objective: Brain natriuretic peptide (BNP) has potent lipolytic action and, probably, a role in the biological mechanisms of obesity. Clinically, high levels are found in subjects with heart failure (HF). Low levels and inverse relation to BMI lead to questioning of its clinical utility in obese subjects, but heterogeneous results are found in severe obesity. Methods: In order to describe BNP behavior and its metabolic and cardiovascular determinants in class III obesity, we performed BNP measurement as well as clinical and echocardiographic evaluation of 89 subjects from two public hospitals in Brazil. Multivariate logistic ordinal regression with BNP tertiles as the dependent variable was performed. Results: Mean ( \pm SD) age and BMI ( \pm SD) was $44 \pm 11.5$ years and $53.2 \pm 7.9 \mathrm{~kg} / \mathrm{m}^{2}$, respectively. 72 (81\%) participants were women, and 18 (20\%) had HF. Median BNP was $9.5 \mathrm{pg} / \mathrm{ml}(\mathrm{Q} 14.9$; $0321.2 \mathrm{pg} / \mathrm{ml}) .30 \%$ of BNP values were below the detection limit of the method. In multivariate analysis, left atrial volume (LAV) was the only determinant of BNP levels ( $p$ 0.002) with odds-ratio of 1.1 (95\% Cl 1.03-1.16). Conclusion: BNP levels are low in severe obesity, even in subjects with HF. LAV, which marks diastolic dysfunction, determines BNP levels, but not BMI and metabolic abnormalities.

\section{Introduction}

Brain natriuretic peptide (BNP) is a 32-amino-acid peptide member of the natriuretic peptides (NP) family, which is released by ventricular cardiomyocytes depending on pressure and volume conditions. Vasodilation, diuresis, natriuresis, and inhibition of the renin-angiotensin-aldosterone and the sympathetic nervous systems are among its hemodynamic actions [1]. It is widely used as a diagnostic and prognostic tool in patients with dyspnea, mainly for exclusion of heart failure (HF). Additionally, the presence of NP receptors in the adipose tissue and the lipolytic action of NP mediated by guanylyl-cyclase pathway have been demonstrated in the recent years, which allow speculations on their involvement in the biological mechanisms of obesity [2].

The prevalence of class III obesity is increasing rapidly among adults [3], and it is an independent risk factor for $\mathrm{HF}$ [4]. Unspecific abnormalities, such as dyspnea and edema are frequent in morbidly obese patients and may be related to mechanic, cardiovascular and pulmonary conditions [5], but physical examination and echocardiogram have limitations in the severe obese population. Hence, BNP may be an important tool for identifying the cause of such abnormalities. In general population, BNP levels are determined not only by systolic and diastolic HF, but also by extracardiac factors such as age, sex, and renal function [6]. Studies with obese patients reveal inverse relation between BNP and BMI and lower BNP levels in lean subjects, even in those with HF [7-9]. Also metabolic abnormalities commonly found in obesity, such as hypertension, diabetes and hyperlipidemia, have been associated with low levels of NP, probably through NP interrelations with the renin-angiotensin-aldosterone and sympathetic nervous systems as well as with insulin, adiponectin and

\section{KARGER \\ Fax +497614520714 \\ Information@Karger.de}

www.karger.com (c) 2011 S. Karger GmbH, Freiburg

$1662-4025 / 11 / 0046-0427 \$ 38.00 / 0$

Accessible online at:

www.karger.com/ofa
Dr. Alline Beleigoli

Universidade Federal de Minas Gerais

Rua Rogério Fajardo, 180/401 Anchieta

30310450-Belo Horizonte, Brazil

beleigoli@yahoo.com 
inflammatory cytokines [10]. Hence, lower cut-points have been proposed to maintain diagnostic accuracy of BNP in the obese subjects [7].

Contradictory data exist regarding the behavior of BNP in severely obese patients [11-13]. Also the factors that determine its serum level are not well studied. The aim of this study is to describe BNP behavior and investigate its metabolic and cardiovascular determinants in a class III obese population.

\section{Patients and Methods}

\section{Study Design and Population}

This cross-sectional study was performed from July 2008 to July 2009. Subjects were recruited from two obesity clinics in Belo Horizonte, Minas Gerais, Brazil (Clinical Hospital of the Universidade Federal de Minas Gerais and Center of Medical Specialties of Santa Casa de Misericórdia). The study was approved by the ethical committees of both institutions, and written informed consent was obtained from all participants.

To be eligible for the study, patients had to have BMI $\geq 40 \mathrm{~kg} / \mathrm{m}^{2}$ and no past history of bariatric surgery. Exclusion criteria were the presence of serum creatinine $\geq 2.0 \mathrm{mg} / \mathrm{dl}$, and the inability to obtain technically adequate echocadiographic data due to body habitus.

\section{BNP Measurement}

Blood samples were collected into tubes containing potassium EDTA. BNP was measured using the Triage BNP Test (Biosite Inc., San Diego, CA, USA). The Triage BNP Test is a fluorescence immunoassay for the quantitative determination of BNP in whole blood and plasma specimens. Precision, analytic sensitivity, and stability characteristics of the system have been described previously [14]. The measurable range of the BNP assay is 5.0 to $1,300.0 \mathrm{pg} / \mathrm{ml}$. BNP values were determined on site by use of the point-of care method with whole blood samples. The maximum interval between blood puncture and measure was $4 \mathrm{~h}$.

\section{Calculation of BMI}

Patients were weighed in light clothing without shoes using a Welmy (capacity up to $300 \mathrm{~kg}$ ) scale with an accuracy of $100 \mathrm{~g}$. Height was measured with a stadiometer with accuracy of $0.5 \mathrm{~cm}$. BMI was calculated using the conventional formula of weight in kilograms divided by the square of height in meters.

\section{Data Collection and Definitions}

Patients were evaluated according to a standard protocol, which included data from the present and past medical history, physical examination, and objective assessment of clinical signs and electrocardiograms. Blood pressure was evaluated using an appropriate sized cuff. At least a 30-min interval from caffeine or cigarette consumption was required before measurement. Glucose and lipids were collected following a 12-hour fasting recommendation. All patients had 12-lead ECG performed. Hypertension was diagnosed according to the 7th Report of the Joint National Committee on Prevention, Detection, Evaluation, and Treatment of High Blood Pressure [15] recommendations or according to history of antihypertensive medication use. Diabetes mellitus was diagnosed in case of two measures of fasting glucose $\geq 126 \mathrm{mg} / \mathrm{dl}$ or history of oral hypoglycemic agents or insulin use. Systolic HF was determined on the basis of the presence of symptoms (dyspnea or fatigue) and signs of fluid retention as well as left ventricular ejection fraction (LVEF) evaluated by echocardiogram below or equal to $50 \%$ [16]. The diagnosis of diastolic
HF was non-invasive and based on the presence of symptoms or signs of $\mathrm{HF}$ and echocardiographic abnormalities according to the recommendations of the $\mathrm{HF}$ and echocardiography associations of the European Society of Cardiology [17]. Subjects with either systolic or diastolic HF were classified as HF.

\section{Echocardiographic Evaluation}

A comprehensive Doppler echocardiogram with color flow mapping and tissue Doppler imaging, was performed in all patients using a commercially available hardware and software (Vivid 7; GE Vingmed Ultrasound AS, Horten, Norway) with an electronic high-resolution transducer of variable frequency $(4-12 \mathrm{MHz})$. All echocardiographic measurements were performed by two experienced physicians who were blinded to the other data of the patients.

Left ventricular (LV) measurements were obtained according to the American Society of Echocardiography standards, and the ejection fraction (EF) was calculated by the Teichholz method [18]. Diastolic function was assessed by pulsed Doppler of the mitral inflow and by tissue Doppler imaging (TDI) [19]. TDI at the medial and lateral border of the mitral annulus were obtained from the apical four-chamber view, and systolic velocity (S), early (e'), late (A') and the ratio between mitral E velocity and mean e' were calculated (E/E').

Left atrial volume (LAV) was assessed by the biplane area-length method from apical 4- and 2-chamber views. Measurements were obtained in end systole from the frame preceding mitral valve opening, and the volume was indexed to height [20].

Doppler-derived strain and strain rates were obtained from the basal part of the six LV walls in three different apical views (septal and lateral walls at the apical 4-chamber view, inferior and anterior at the apical 2-chamber, and posterior and antero-septal at the 3-chamber apical). These measurements were also obtained for the right ventricle at its basal free wall in the apical 4-chamber view.

\section{Statistical Analysis}

$\mathrm{BNP}$ and patient characteristics were described by median and interquartile ranges, or means and standard deviation (SD) for normal data. Frequency was calculated for categorical variables. Three groups were established on the basis of the BNP tertiles obtained from the population. Univariate analysis was performed by comparisons of clinical, laboratorial and echocardiographic characteristics among the groups, using $\chi^{2}$ tests for categorical data and the Kruskal-Wallis test for continuous data. BNP values were also compared between the HF and non-HF groups using the Mann-Whitney U test.

We performed multivariable logistic ordinal regression, in order to study the determinants of BNP levels in the population. Proportionalodds model was chosen among the ordinal logistic regression models for being the most appropriate in dealing with continuous variables grouped into categories. Variables considered to be clinically relevant entered the logistic regression, independent of univariate analysis results. Those with statistical significance $(\mathrm{p} \leq 0.25)$ in univariate analysis entered the model as well. Co-variables examined for inclusion in the multivariable model were: age, gender, heart rate, BMI, systolic arterial pressure, creatinine, LAV, left ventricular end-systolic diameter, deceleration time mitral inflow (DT), LVEF, left ventricular mass indexed to height ${ }^{2.7}$, E/E' (E' was the average of septal and lateral mitral annular early diastolic velocity), right ventricular strain and strain rate, and the average value of the strain and strain rate of the LV six basal walls. The ordinal logistic model was adjusted using backward criteria, and variables with $\mathrm{p}$ value $\leq 0.05$ were individually retained in the model. Odds ratio (OR) was calculated for each co-variable, and a unique OR estimation was given for all compared categories based on the assumption of constant OR for all categories in this type of model. This assumption was tested by the parallel line test for each variable and for the final model. Model fitting was evaluated by Deviance test [21]. 
Table 1. Patients baseline clinical and laboratorial characteristics according to BNP group and overall

\begin{tabular}{|c|c|c|c|c|c|}
\hline Variable & $\begin{array}{l}\text { Overall } \\
(\text { mean } \pm \text { SD }), \%\end{array}$ & $\mathrm{BNP}<5.2$ & $5.2 \leq \mathrm{BNP} \leq 17.1$ & $\mathrm{BNP}>17.1$ & $\mathrm{p}$ value $^{\mathrm{a}}$ \\
\hline \multicolumn{6}{|l|}{ Clinical history } \\
\hline Age, years & $44 \pm 11.5$ & 40 & 45 & 46 & 0.11 \\
\hline Female, \% & 81 & 77 & 79 & 86 & 0.66 \\
\hline Dyspnea, \% & 80 & 81 & 79 & 79 & 0.99 \\
\hline NYHA III or IV $^{\mathrm{b}}, \%$ & 17 & 13 & 14 & 24 & 0.44 \\
\hline Orthopnea, \% & 41 & 40 & 50 & 35 & 0.48 \\
\hline PND, \% & 24 & 27 & 21 & 24 & 0.90 \\
\hline Beta-blocker, \% & 24 & 23 & 21 & 28 & 0.82 \\
\hline \multicolumn{6}{|l|}{ Comorbidities } \\
\hline Hypertension, \% & 78 & 77 & 76 & 79 & 0.95 \\
\hline Diabetes, \% & 35 & 32 & 43 & 31 & 0.59 \\
\hline $\mathrm{MS}^{\mathrm{c}}, \%$ & 78 & 81 & 79 & 72 & 0.72 \\
\hline $\mathrm{CD}^{\mathrm{d}}, \%$ & 3 & 3 & 0 & 7 & 0.35 \\
\hline $\mathrm{PD}^{\mathrm{e}}, \%$ & 27 & 35 & 17 & 28 & 0.28 \\
\hline $\mathrm{MR}^{\mathrm{f}}, \%$ & 1.3 & 0 & 0 & 4.2 & 0.34 \\
\hline $\mathrm{AF}, \%$ & 3.4 & 0 & 3.4 & 6.9 & 0.55 \\
\hline $\mathrm{HF}, \%$ & 20 & 16 & 14 & 31 & 0.20 \\
\hline \multicolumn{6}{|l|}{ Physical exam } \\
\hline $\mathrm{BMI}, \mathrm{kg} / \mathrm{m}^{2}$ & $53.2 \pm 7.9$ & 51.5 & 52.8 & 55.1 & 0.21 \\
\hline $\mathrm{SP}, \mathrm{mm} \mathrm{Hg}$ & $141 \pm 23$ & 137 & 139 & 146 & 0.29 \\
\hline $\mathrm{DP}, \mathrm{mm} \mathrm{Hg}$ & $87 \pm 17$ & 85 & 88 & 89 & 0.81 \\
\hline Waist, cm & $138 \pm 14$ & 136 & 140 & 138 & 0.41 \\
\hline Waist/hip ratio & $0.94 \pm 0.09$ & 0.94 & 0.95 & 0.94 & 0.82 \\
\hline Leg edema, \% & 64 & 58 & 65 & 65 & 0.56 \\
\hline \multicolumn{6}{|l|}{ Laboratory data } \\
\hline Fasting glucose, $\mathrm{mg} / \mathrm{dl}$ & $107 \pm 35$ & 104 & 112 & 106 & 0.41 \\
\hline Cholesterol, mg/dl & $192 \pm 49$ & 195 & 189 & 191 & 0.91 \\
\hline Creatinine, g/dl & $0.9 \pm 0.2$ & 0.8 & 0.9 & 0.8 & 0.77 \\
\hline $\begin{array}{l}\text { PND = Paroxysmal noc } \\
{ }^{\mathrm{a}} \mathrm{p} \text { values are for compa } \\
{ }^{\mathrm{b}} \text { Stages of dyspnea acce } \\
{ }^{\mathrm{c}} \text { Metabolic syndrome a } \\
{ }^{\mathrm{d}} \text { Self-reported history } \\
\text { e'Self-reported history } \\
{ }^{\mathrm{f}} \text { Moderate to severe mi }\end{array}$ & $\begin{array}{l}1 \text { dyspnea; AF = at } \\
\text { among } 3 \text { BNP gro } \\
\text { to the New York } \\
\text { ng to ATP III crit } \\
\text { e coronary syndro } \\
\text { nonary disease (as } \\
\text { gurgitation. }\end{array}$ & $\begin{array}{l}\text { prillation; S } \\
\text { Associatior }\end{array}$ & $\begin{array}{l}\text { stolic blood press } \\
\text { roxysmal nocturna }\end{array}$ & $\begin{array}{l}\mathrm{P}=\text { diastolic } \\
\text { pnea. }\end{array}$ & d pressure \\
\hline
\end{tabular}

\section{Results}

101 class 3 obese patients were recruited. Twelve of them were excluded because of technically inadequate echocardiographic images. According to the BNP tertiles, three groups were established: $\mathrm{BNP}<5.2 \mathrm{pg} / \mathrm{ml}, 5.2 \leq \mathrm{BNP} \leq 17.1 \mathrm{pg} / \mathrm{ml}$, BNP $>17.1 \mathrm{pg} / \mathrm{ml}$. The first group consisted of 31, and the second and third groups of 29 subjects each. Mean (SD) age and BMI were $44(11.5)$ years and $53.2(7.9) \mathrm{kg} / \mathrm{m}^{2}$, respectively. Females $(81 \%)$ were predominant. Hypertension was present in $70(78 \%)$, dyspnea in $71(80 \%)$, and HF in $18(20 \%)$ of the participants. Patients' baseline clinical and laboratorial characteristics according to BNP group and overall are depicted in table 1. Echocardiographic data for BNP groups and overall are displayed in table 2.

BNP showed a non-normal distribution with median value of $9.5 \mathrm{pg} / \mathrm{ml}$ (Q1 $4.9 \mathrm{pg} / \mathrm{ml}$; Q3 21.2 pg/ml). BNP values ranged from inferior to $5.0 \mathrm{pg} / \mathrm{ml}$ to $151.0 \mathrm{pg} / \mathrm{ml} .30 \%$ of the observed values were below the inferior limit of detection of the method $(5.0 \mathrm{pg} / \mathrm{ml})$. Only $4 \%$ of the subjects had BNP levels above $100 \mathrm{pg} / \mathrm{ml}$. Median BNP values were 9.1 (IQ 4.9-19.9) and 17.5 (IQ 5.1-27.3) $\mathrm{pg} / \mathrm{ml}$ in the non-HF and HF group, respectively $(\mathrm{p}=0.14)$.

Age $(p=0.11)$, heart rate $(p=0.03)$, BMI $(p=0.21)$, LAV $(p=0.01)$ and left ventricular strain rate $(p=0.12)$ were selected by univariate analysis. In multivariable analysis, LAV was the only variable retained in the model $(p=0.002)$. OR for LAV was 1.1 (95\% CI 1.03-1.16), which means that a $1 \mathrm{ml} / \mathrm{m}$ increment in LAV increases the odds of having BNP levels in a superior category in $10 \%$. In our sample, $37 \%$ of the male participants and $42 \%$ of female subjects had LA enlargement, when considering indexation to height and ref- 
Table 2. Echocardiographic data according to BNP group and overall

\begin{tabular}{lllllll}
\hline Variable & Overall mean & Overall SD & BNP $<5.2$ & $5.2 \leq$ BNP $\leq 17.1$ & BNP $>17.1$ & $p_{\text {value }}$ \\
\hline LVEF, \% & 65.8 & 7.9 & 67 & 65 & 65 & 0.76 \\
LAV, mL/m & 37.4 & 9.9 & 32.9 & 36.4 & 43.5 & 0.01 \\
LVEDD, mm & 51.1 & 3.8 & 51 & 50 & 52 & 0.35 \\
LVESD, mm & 32.2 & 4.6 & 32 & 32 & 33 & 0.59 \\
E/A & 1.2 & 0.4 & 1.1 & 1.1 & 1.2 & 0.39 \\
E/E & & & & & 8.7 & 0.97 \\
$\quad$ Average & 8.5 & 2.6 & 8.4 & 8.4 & 10.3 & 0.46 \\
$\quad$ Lateral & 8.9 & 7.4 & 9.2 & 7.5 & 9.6 & 0.83 \\
$\quad$ Septal & 9.8 & 5.3 & 10.4 & 9.3 & 242 & 0.93 \\
DTd, ms & 243 & 50.6 & 245 & 244 & -23.2 & 0.54 \\
Strain (average) & -22.4 & -3.2 & -22.4 & -22.2 & -1.7 & 0.12 \\
Strain rate (average) & -1.5 & -0.3 & -1.5 & -1.5 & \\
\hline
\end{tabular}

LVEF = Left ventricle ejection fraction; LVEDD = left ventricle end-diastolic diameter; LVESD = left ventricle end-systolic diameter;

${ }^{\mathrm{a}} \mathrm{p}$ values are for comparisons among 3 BNP groups.

${ }^{\mathrm{b}}$ Ratio of peak early to peak atrial Doppler flow velocity.

${ }^{\mathrm{c}}$ Ratio of transmitral early diastolic velocity to mitral annular early diastolic velocity.

${ }^{\mathrm{d} D e c e l e r a t i o n ~ t i m e ~ m i t r a l ~ i n f l o w . ~}$

Fig. 1. Association between left atrial volume (LAV) and BNP groups.

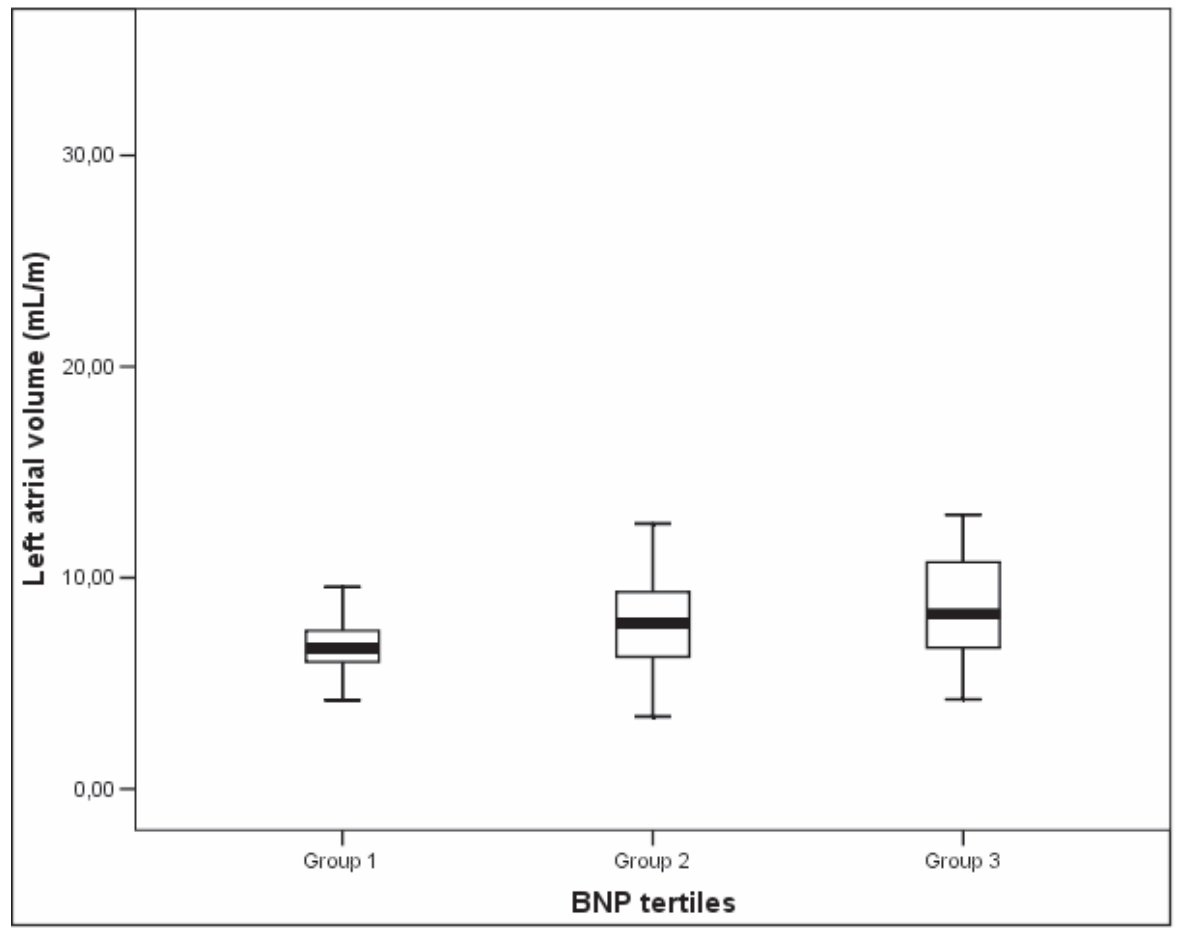

erence values of $35.7 \mathrm{ml} / \mathrm{m}$ for men and $33.7 \mathrm{ml} / \mathrm{m}$ for women [22]. The association between LAV and BNP groups is depicted in figure 1 .

\section{Discussion}

The behavior of BNP levels in severely obese subjects is yet undefined. As verified by a recent review made by our group, BNP behavior and its correlation with BMI in class 3 obese subjects reveals contradictory results [13]. Since physical examination and echocardiogram have limitations in the severely obese population, BNP may aid in the differential diagnosis of unspecific abnormalities, such as dyspnea and edema, which may be caused by mechanic, cardiovascular, and/or pulmonary conditions [5]. Moreover, since this population increases more importantly than any other class of obesity and the risk for HF more than doubles in the upper BMI categories [4], the determination of BNP behavior is fundamental for its clinical use [3]. Findings of diminished NP levels in obese patients and in- 
verse relation between BNP and BMI lead to questioning of NP diagnostic and prognostic utility in the diagnosis of HF in subjects in the upper BMI extracts [7, 8]. Our data depicts low BNP levels in severely obese patients, with $30 \%$ of the population showing values below the limit of detection of the test. We did not find any relation between BNP and BMI, which may be attributable to the homogeneously high BMI levels throughout the population that did not allow correlation to be statistically significant. Moreover, contrary to previous studies, the presence of diabetes and other risk factors for the metabolic syndrome did not have any impact on BNP levels [10,23].

The low levels of NP in obese patients allow speculations on their role in the pathophysiology and perpetuation of obesity. NP are lipolytic agents as potent as the catecholamines and are specific of lipolysis in primates [24]. Experimental and clinical studies have demonstrated their role in the adipocytes in the subcutaneous and visceral adipose tissue [25] and during exercise-induced lipolysis [26]. NP link to type A transmembrane guanylyl-cyclase family receptors in the adipose tissue, which results in the activation of the cyclic guanosine monophosphate(cGMP)-dependent signaling cascade. This pathway promotes hydrolyzation of triglycerides into non-esterified fatty acids and glycerol [2]. Contrary to the catecholamine pathway, which has cyclic adenosine monophosphate (cAMP) as a second messenger, insulin is not an important inhibitor of NP-induced lipolysis [27]. Possible explanations for the lower BNP levels in obese subjects in comparison to the lean ones are increased degradation of the peptide by greater quantities of clearance receptors (type $\mathrm{C}$ receptors) in the adipose tissue and/or by increased action of neprilysins in the endothelium [28]. However, findings of low NT-proBNP levels, a precursor of BNP which is not cleared by type $\mathrm{C}$ receptors, in obese patients makes the former a less probable explanation [29].

LAV was the only determinant of BNP levels in this severely obese group. In the absence of valve disease and atrial fibrillation, which is the case in our population (table 1), LAV reflects either volume overload or elevated ventricular filling pressures [30]. Increased blood volume and hyperdynamic circulation result from the augmented metabolic demand generated by the excess of adipose tissue and fat-free mass in obesity. Thus, stroke volume and cardiac output increase and LAV may enlarge in response to these alterations [31]. Moreover, obesity itself is a direct cause of structural cardiac abnormalities and the cardiomyopathy of obesity, which is mediated not only by hemodynamic alterations but also by the obesity-associated inflammatory state, lipotoxicity, and insulin resistance [32]. Recently it was demonstrated in a population-based cohort that obesity is the main risk factor for LA enlargement [22], which is a biomarker of cardiovascular risk, atrial fibrillation, stroke, and death [30]. BNP, as well, has been increasingly recognized as an independent prognostic determinant of morbidity and mortality [33].

LA enlargement also occurs because of pressure overload due to increased LV stiffness, associated with diastolic dys- function. During diastole, the LAV is directly exposed to pressures in the LV. Once these pressures are increased by decreased LV compliance or increased stiffness, LA pressure increases to maintain adequate filling. This leads to increased atrial wall tension, chamber dilatation, and stretching of the atrial myocardium. Diastolic dysfunction is a prevalent alteration in the myocardium of obese subjects [34] and LAV provides long-term view of chronic diastolic dysfunction, regardless of the loading conditions present at the time of the examination [35]. The present study has 15 participants (17\%) with diastolic HF. However, it was not possible to demonstrate relation between BNP levels and Doppler and TDI assessment of instantaneous filling pressure, which reflect hemodynamic status in the short term [30]. Since our patients are ambulatory in origin and did not present with symptoms or signs of acute cardiac failure, it was not expected high LV filling pressures during examination. Poor concordance among echocardiography measures of diastolic function was also found by Petrie et al. [36] in their cohort study.

This study has several limitations. First, diastolic HF cases may have been underestimated due to lack of echocardiographic data regarding the duration of reverse pulmonary vein atrial systole flow and duration of mitral valve atrial wave flow measures. These measures were not possible because of technical limitations related to the patients' body habitus. Secondly, it was not possible to perform sleep studies, and the effect of obstructive sleep apnea on BNP levels is unpredictable since studies addressing the correlation between NP levels and this prevalent condition in obese patients show conflicting results [37]. Finally, the relatively small number of participants with HF, especially with the systolic form, does not allow definitive conclusions about the behavior of BNP in obese patients with HF.

In conclusion, BNP levels are very low in severely obese patients and are not determined by BMI or metabolic risk factors. LAV is the only predictor of BNP in this population, which probably indicates that the peptide maintains its utility in detecting volume overload states and diastolic dysfunction associated with obesity, despite the low levels. Larger studies with HF subjects are required to investigate BNP utility in identifying this condition in class III obese patients.

\section{Acknowledgements}

The authors would like to thank Dr. Cláudia Maria Vieira Fernandes for her precious help in the subjects recruitment process, and Fundação de Amparo à Pesquisa do Estado de Minas Gerais (FAPEMIG), Belo Horizonte, Brazil, and Conselho Nacional do Desenvolvimento Científico e Tecnológico (CNPq), Brazil, for supporting this study.

\section{Disclosure Statement}

The authors have no conflicts of interest. 


\section{References}

1 Koller KJ, Goeddel DV: Molecular biology of the natriuretic peptides and their receptors. Circulation 1992;86:1081-1088.

2 Sengenes C, Berlan M, De Glisezinski I, Lafontan M, Galitzky J: Natriuretic peptides: a new lipolytic pathway in human adipocytes. FASEB J 2000;14: 1345-1351.

>3 Freedman DS, Khan LK, Serdula MK, Galuska DA, Dietz WH: Trends and correlates of class 3 obesity in the united states from 1990 through 2000. JAMA 2002;288:1758-1761.

4 Kenchaiah S, Evans JC, Levy D, Wilson PWF, Benjamin EJ, Larson MG, Kannel WB, Vasan RS: Obesity and the risk of heart failure. N Engl J Med 2002;347:305-313.

$\checkmark 5$ Ferreti A, Giampiccolo P, Cavalli A, Milic-Emili J, Tantucci C: Expiratory flow limitation and orthopnea in massively obese subjects. Chest 2001;119: 1401-1408.

6 Wang TJ, Larson MG, Levy D, Leip EP, Benjamin EJ, Wilson PWF, Sutherland P, Omland T, Vasan RS: Impact of age and sex on plasma natriuretic peptide levels in healthy adults. Am J Cardiol 2002; 90:254-258.

7 Daniels L, Clopton P, Bhalla V, Krishnaswamy P, Nowak R, McCord J, Hollander J, Duc P, Omland T, Storrow A, Abraham W, Wu A, Steg P, Westheim A, Knudsen C, Perez A, Kazanegra R, Herrmann $\mathrm{H}$, McCullough $\mathrm{P}$, Maisel A: How obesity affects the cut-points for B-type natriuretic peptide in the diagnosis of acute heart failure. Results from the Breathing Not Properly Multinational Study. Am Heart J 2006;151:999-1005.

8 Dokainish H, Gonzalez R, Hartley WB, Caldera A, Koshy S, Sengupta R, Lakkis NM: Usefulness of B-type natriuretic peptide levels to predict left ventricular filling pressures in patients with body mass index $>35,31$ to 35 , and $\leq 30 \mathrm{~kg} / \mathrm{m}^{2}$. Am J Cardiol 2007;100:1166-1171.

$\checkmark 9$ Mehra M, Uber P, Park M, Scott R, Ventura H, Harris B, Frohlich E: Obesity and suppressed Btype natriuretic peptide levels in heart failure. $\mathrm{J}$ Am Coll Cardiol 2004;43:1590-1595.

10 Wang TJ, Larson MG, Keyes MJ, Levy D, Benjamin EJ, Vasan RS: Association of plasma natriuretic peptide levels with metabolic risk factors in ambulatory individuals. Circulation 2007;115:13451353

11 Hanusch-Enserer U, Hermann KM, Cauza E, Spak M, Mähr B, Dunky A, Rosen HR, Köller U, Prager $\mathrm{R}$ : Effect of gastric banding on aminoterminal probrain natriuretic peptide in the morbidly obese. Obes Res 2003;11:695-698.

-12 St Peter JV, Hartley GG, Murakami MM, Apple FS: B-type natriuretic peptide (BNP) and N-terminal pro-BNP in obese patients without heart failure: relationship to body mass index and gastric bypass surgery. Clin Chem 2006;52:680-685.

13 Beleigoli A, Diniz M, Ribeiro A: Natriuretic peptides: linking heart and adipose tissue in obesity and related conditions - a systematic review. Obes Rev 2009;10:617-626.

14 Mair J, Hammerer-Lercher A, Puschendorf B: The impact of cardiac natriuretic peptide determination on the diagnosis and management of heart failure. Clin Chem Lab Med 2001;39:571-588.

15 Chobanian A, Bakris G, Black H, Cushman W, Green L, Izzo J Jr, Jones D, Materson B, Oparil S, Wright J Jr: The seventh report of the joint national committee on prevention, detection, evaluation, and treatment of high blood pressure. JAMA 2003;289:2560-2572.
16 Hunt SA, Abraham WT, Chin MH, Feldman AM, Francis GS, Ganiats TG, Jessup M, Konstam MA, Mancini DM, Michl K, Oates JA, Rahko PS, Silver MA, Warner SL, Yancy CW: 2009 focused update incorporated into the ACC/AHA 2005 guidelines for the diagnosis and management of heart failure in adults. a report of the American College of Cardiology Foundation/American Heart Association Task Force on Practice Guidelines. J Am Coll Cardiol 2009;53:e1-e90.

17 Paulus WJ, Tschöpe C, Sanderson JE, Rusconi C, Flachskampf FA, Rademakers FE, Marino P, Smiseth OA, De Keulenaer G, Leite-Moreira AF, István E'des ABl, Handoko ML, Heymans S, Pezzali N, Pieske B, Dickstein K, Fraser AG, Brutsaert DL: How to diagnose diastolic heart failure: a consensus statement on the diagnosis of heart failure with normal left ventricular ejection fraction by the heart failure and echocardiography associations of the European Society of Cardiology. Eur Heart J 2007;28:2539-2550.

18 Lang R, Bierig M, Devereux R, Flachskampf F, Foster E, Pellikka P, Picard M, Roman M, Seward J, Shanewise J, Solomon S, Spencer K, Sutton M, Stewart W, Grou CQW, Committee ASoEsGaS, Echocardiography EAo: Recommendations for chamber quantification: A report from the American Society of Echocardiography's guidelines and Standards Committee and the Chamber Quantification Writing Group, developed in conjunction with the European Association of Echocardiography, a branch of the European Society of Cardiology. J Am Soc Echocardiogr 2005;18:1440-1463.

19 Nagueh S, Middleton K, Kopelen H, Zoghbi W, Quinones M: Doppler tissue imaging: a noninvasive technique for evaluation of left ventricular relaxation and estimation of filling pressures. J Am Coll Cardiol 1997;30:1527-1533.

-20 Wang Y, Gutman J, Heilbron D, Wahr D, Schiller $\mathrm{N}$ : Atrial volume in a normal adult population by two-dimensional echocardiography. Chest 1984;86: 595-601.

21 Ananth C, Kleinbaum D: Regression models for ordinal responses: a review of methods and applications. Int J Epidemiol 1997;26:1323-1333.

22 Stritzke J, Markus MRP, Duderstadt S, Lieb W, Luchner A, Döring A, Keil U, Hense H-W, Schunkert $\mathrm{H}$ : The aging process of the heart: obesity is the main risk factor for left atrial enlargement during aging. The MONICA/KORA (Monitoring of Trends and Determinations in Cardiovascular Disease/ Cooperative Research in the Region of Augsburg) study. J Am Coll Cardiol 2009;54:1982-1989.

23 Olsen MH, Hansen TW, Christensen MK, Gustafsson F, Rasmussen S, Wachtell K, Borch-Johnsen K, Ibsen $\mathrm{H}$, Jorgensen T, Hildebrandt P: N-terminal pro brain natriuretic peptide is inversely related to metabolic cardiovascular risk factors and the metabolic syndrome. Hypertension 2005;46:660-666.

24 Sengenes C, Zakaroff-Girard A, Moulin A, Berlan M, Bouloumie A, Lafontan M, Galitzky J: Natriuretic peptide-dependent lipolysis in fat cells is a primate specificity. Am J Physiol Reg Int Comp Physiol 2002;283:R257-R265.
5 Sarzani R, Marcucci P, Salvi F, Bordicchia M, Espinosa E, Mucci L, Lorenzetti B, Minardi D Muzzonigro G, Dessi-Fulgheri P, Rappelli A: Angiotensin II stimulates and atrial natriuretic peptide inhibits human visceral adipocyte growth. Int J Obes 2008;32:259-267.

26 Moro C, Pillard F, Glisezinski I, Klimcakova E, Crampes F, Thalamas C, Harant I, Marques M-A Lafontan M, Berlan M: Exercise-induced lipid mobilization in subcutaneous adipose tissue is mainly related to natriuretic peptides in overweight men. Am J Physiol Endocrinol Metab 2008;295:E505E513.

27 Moro C, Polak J, Richterova B, Sengenes C, Pelikanova T, Galitzky J, Stich V, Lafontan M, Berlan M: Differential regulation of atrial natriuretic peptide- and adrenergic receptor-dependent lipolytic pathways in human adipose tissue. Metabolism Clin Exp 2005;54:122-131.

28 Moro C, Galitzky J, Sengenes C, Crampes F, Lafontan M, Berlan M: Functional and pharmacological characterization of the natriuretic peptidedependent lipolytic pathway in human fat cells. J Pharm Exp Therap 2004;308:984-992.

29 Rivera M, Cortes R, Salvador A, Bertomeu V, de Burgos FG, Paya R, Portoles M, Talens-Viscont R, Martinez-Dolz L, Valero R, Sevilla B, Climent $\mathrm{V}$ : Obese subjects with heart failure have lower $\mathrm{N}$-terminal pro-brain natriuretic peptide plasma levels irrespective of aetiology. Eur J Heart Fail 2005;7:1168-1170.

30 Tsang TSM, Barnes ME, Gersh BJ, Bailey KR, Seward JB: Left atrial volume as a morphophysiologic expression of left ventricular diastolic dysfunction and relation to cardiovascular risk burden. Am J Cardiol 2002;90:1284-1289.

31 Alpert MA: Obesity cardiomyopathy: pathophysiology and evolution of the clinical syndrome. Am J Med Sci 2001;321:225-236.

32 Pascual M, Pascual DA, Soria F, Vicente T, Hernández AM, Tébar FJ, Valdés M: Effects of isolated obesity on systolic and diastolic left ventricular function. Heart 2003;89:1152-1156.

33 Horwich TB, Hamilton MA, Fonarow GC: B-type natriuretic peptide levels in obese patients with advanced heart failure. J Am Coll Cardiol 2006;47: 85-90.

34 Schunkert H: Obesity and target organ damage: the heart. Int J Obes 2002;26(suppl 4):S15-S20.

35 Douglas PS: The left atrium. A biomarker of chronic diastolic dysfunction and cardiovascular disease risk. J Am Coll Cardiol 2003;42:1206-1207.

36 Petrie MC, Hogg K, Caruana L, McMurray JJV: Poor concordance of commonly used echocardiographic measures of left ventricular diastolic function in patients with suspected heart failure but preserved systolic function: is there a reliable echocardiographic measure of diastolic dysfunction? Heart 2004;90:511-517.

37 Patwardhan AA, Larson MG, Levy D, Benjamin EJ, Leip EP, Keyes MJ, Wang TJ, Gottlieb DJ, Vasan RS: Obstructive sleep apnea and plasma natriuretic peptide levels in a community-based sample. Sleep 2006;29:1301-1306. 